\title{
Investigations of detrital zircon, rutile and titanite from present-day Labrador drainage basins: fingerprinting the Grenvillean front
}

\author{
Tonny B. Thomsen, Christian Knudsen and Alana M. Hinchey
}

A multidisciplinary provenance study was conducted on stream sediment samples from major rivers in the eastern part of Labrador, Canada (Fig. 1). The purpose was to fingerprint the sources that deliver material to the stream sediments and to the reservoir sand units deposited offshore in the sedimentary basins in the Labrador Sea. We used a multimineral U-Pb geochronological approach employing rutile and titanite in addition to zircon to obtain unbiased age data. The purpose of this was to characterise the different igneous and metamorphic episodes that occurred in Labrador, which is an area with highly variable geology characterised by the Palaeoproterozoic south-eastern Churchill province in the north-west, the Archaean Nain plutonic suite in the north-east, the Palaeoproterozoic Makkovik province in the east and the Mesoproterozoic Grenville Province to the south. The field work was carried out in 2012 and 2013 and the study is a collaborative project between the Geological Survey of Denmark and Greenland and the Geological Survey of Newfoundland and Labrador. In this paper we focus on three samples from the southern part of the study area where two parts of the Grenville orogeny are found (Fig. 1).

\section{The use of zircon, rutile and titanite in sedimentary provenance investigations}

Methods for obtaining geochronological information from various detrital minerals for quantitative sedimentary provenance purposes have developed rapidly over recent years. This is mostly due to advances in high-throughput microanalytical techniques such as Laser Ablation Inductively Coupled Plasma Mass Spectrometry (LA-ICPMS). The emphasis on $\mathrm{U}-\mathrm{Pb}$ geochronology has primarily been on detrital zircon, as it typically provides precise age information of the source rocks. Zircon, however, is not usually the mineral of choice for dating the history of rocks with a complex tectonothermal evolution, as it typically survives most processes occurring in the rock cycle from sedimentation to high grade metamorphism and often even magmatic processes. This means that zircon typically reflects several orogenic cycles (e.g. Okay et al. 2011) and is less suited for recording information about processes related to the metamorphic or hydrothermal reaction history of a rock.

The Ti minerals, rutile and titanite, occur in a variety of magmatic, hydrothermal, metamorphic and sedimentary rock types, often together with zircon (e.g. Force 1991; Frost et al. 2001; Zack et al. 2004). Although detrital rutile is less abundant than zircon, the widespread occurrence of rutile in a wide range of medium- to high-grade, and also high-pressure (blueschist and eclogite facies), metamorphic rocks as well as in sediments and sedimentary rocks (Force 1980, 1991), combined with its high mechanical and chemical stability during weathering, transport and diagenesis (e.g. Morton \& Hallsworth 1999), makes it a prime candidate in provenance studies (Zack et al. 2011). Rutile forms under amphibolite and higher metamorphic facies conditions and is typically unstable at lower grade conditions (Force 1980,

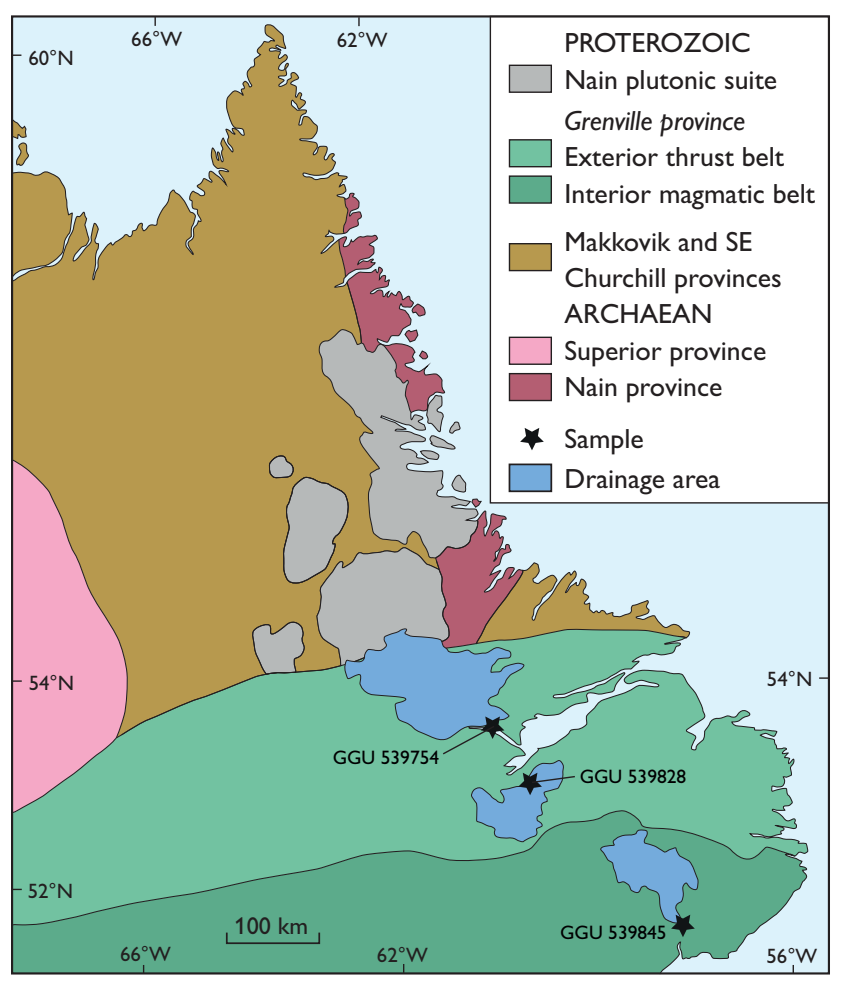

Fig. 1. Simplified geological map of Labrador. 
1991; Triebold et al. 2007, 2011), where it usually breaks down to form other Ti minerals such as titanite or ilmenite at greenschist facies conditions. Rutile, therefore, typically yields chronological and petrogenetic information reflecting the timing and conditions of the last medium to high-grade or high-pressure metamorphic event (Zack et al. 2011; Okay etal. 2011).

Titanite is widespread in a variety of rock types typically of more calcic compositions, and is usually rare in rocks with low $\mathrm{CaO} / \mathrm{Al}_{2} \mathrm{O}_{3}$ ratios such as peralkaline granitoids and peraluminous granites (Frost et al. 2001). Titanite occurs in very low- to high-grade metamorphic rocks and survives under ultra-high pressure conditions (Force 1991; Frost et al. 2001), although it is typically scarce or absent in most granulite-facies metamorphic rocks (Krogh \& Keppie 1990). Even though titanite is a widespread mineral and occurs as detrital and authigenic grains in sedimentary rocks, it has rarely been used to date deposition, diagenesis or low-grade metamorphism. Detrital titanite was first used as a sedimentary provenance tool by McAteer et al. (2010). The reason that titanite is not routinely used for provenance investigations is probably that it is more susceptible to abrasion during sedimentary transport than zircon and rutile, resulting in reduced occurrence or absence as a detrital component in sediments and sedimentary rocks. Titanite, however, is more reactive than zircon or rutile during metamorphism and forms at temperatures below $700^{\circ} \mathrm{C}$. This provides the mineral with a large potential to record ages for a wide range of low to moderate temperature geological crustal processes (Frost et al. 2001; McAteer et al. 2010; Muhling et al. 2012). Thus, if present in sedimentary rocks, titanite is an ideal candidate for dating regional or local metamorphism. In addition, because most metamorphic events are associated with deformation, titanite can date potential deformation stages in metamorphic terranes (Frost et al. 2001).

Therefore, it is possible to recognise sediment sources from detrital titanite and rutile data that are not represented in zircon data and thus gain additional chronological and petrogenetic insight into the tectonothermal history of the source regions (McAteer et al. 2010, 2014). Furthermore, rutile and titanite generally contain 5-10 times less $U$ than zircon, thus metamictisation of these minerals is relatively rare. Consequently, in rocks with U-rich zircon and titanite or rutile, the zircon might show metamictisation, and therefore would be more prone to degradation during transport and weathering, and is thus likely to be excluded from a detrital study (Fedo et al. 2003). Titanite and rutile, on the other hand, have the potential to retain the magmatic record of the U-rich zircon source as well as the metamorphic episodes that may have occurred prior to deposition.

\section{U-Pb analysis and data processing}

In this study, $\mathrm{U}-\mathrm{Pb}$ dating was carried out on mineral grains embedded in epoxy mounts at the LA-ICPMS facility at the Geological Survey of Denmark and Greenland using a NWR213 Nd:YAG laser system coupled to an ELEMENT 2 double-focusing, single-collector, magnetic sector-field ICPMS. Mineral grains were separated by routine separation methods including a Wilfrey water-shaking table, Frantz electromagnetic separation and heavy liquids. Zircon, rutile and titanite grains were picked by hand under a binocular microscope from the resulting heavy mineral fractions and mineral compositions were qualitatively controlled by SEMEDS. For rutile and titanite, laser beam pre-ablation using a spot size slightly larger $(40 \mu \mathrm{m})$ than the analysis spot size $(25 \mu \mathrm{m})$ was performed prior to the LA-ICPMS analysis to avoid surface contamination. Data processing was performed off-line using the software Iolite (Paton et al. 2010, 2011) and the VizualAge data reduction scheme vers. 2.5 by Petrus \& Kamber (2012). The data were corrected for background signal, time-dependent fractionation, instrumental drift and down-hole isotopic fractionation. In order to validate our results, the measurements were bracketed throughout the entire analysis sequences by analyses of natural mineral standards. These include the GJ-1 and Plesovice zircons, the rutiles R10, R13, R19 (provided by courtesy of T. Zack, University of Gothenburg) and Sugluk-4 (L. Bracciali, British Geological Survey), and the titanite A1772 (Y. LaHaye, Geological Survey of Finland) and Seiland (J. Kosler, University of Bergen). In contrast to zircon, common $\mathrm{Pb}$ in titanite and rutile is generally lattice bound and can occur in significant proportions. Thus, common $\mathrm{Pb}$ correction typically needs to be applied for these minerals. However, common $\mathrm{Pb}$ usually has negligible effects for titanites or rutiles with ${ }^{206} \mathrm{~Pb} /{ }^{204} \mathrm{~Pb}$ ratios $>300$ (Frost et al. 2001), whereas the initial common $\mathrm{Pb}$ isotopic composition typically has greater effects on analyses with ${ }^{206} \mathrm{~Pb} /{ }^{204} \mathrm{~Pb}$ ratios $<300$ and therefore the results must be treated more cautiously. Only the titanite grains in this study typically have large proportions of common $\mathrm{Pb}$, whereas most zircon and rutile only contain a small or negliable amount of common $\mathrm{Pb}$. Titanite ages reported herein are corrected for common $\mathrm{Pb}$. Some of the titanite grains contained a significant amount of common $\mathrm{Pb}$ and some of the titanite ages are potentially of a slightly lower accuracy compared to ages obtained for rutile and zircon that were not common $\mathrm{Pb}$ corrected. The correction for common $\mathrm{Pb}$ was performed using the present-day terrestrial common $\mathrm{Pb}$ estimate of Stacey \& Kramers (1975) and the measured mass $204\left({ }^{204} \mathrm{~Pb}+{ }^{204} \mathrm{Hg}\right)$ corrected for ${ }^{204} \mathrm{Hg}$ calculated from measured ${ }^{202} \mathrm{Hg}$ and the natural ${ }^{204} \mathrm{Hg} /{ }^{202} \mathrm{Hg}$ ratio. 


\section{Results of the provenance study}

$\mathrm{U}-\mathrm{Pb}$ age distributions of zircon, rutile and titanite from three representative river samples are shown in the probability-density diagrams in Fig. 2. The three samples were collected in areas within the Grenvillean orogenic belt that are characterised by ages around $1000 \mathrm{Ma}$. Sample GGU 539754 comes from the northern part of the orogenic belt (the exterior thrust belt), sample GGU 539828 from the central part and sample GGU 539845 from the southern part (the interior magmatic belt). The samples all contain zircon grains older than the Grenville orogeny, reflecting the ability of zircon to maintain older magmatic formation signatures through the younger Grenvillean orogenesis. The three areas show distinct differences in detrital zircon ages. The frequency of $c .1000 \mathrm{Ma}$ old Grenvillean zircon ages is much lower in the northern exterior thrust belt than in the central part and especially in the southern interior magmatic belt, where crust was formed during the Grenville orogeny. In the southern area (GGU 539845) both Palaeo- and Mesoproterozoic zircon ages are common, with the highest abundance at c. $1500 \mathrm{Ma}$, whereas the samples from the central area (GGU 539828) and the northern exterior thrust belt (GGU 539754) are dominated by Palaeoproterozoic zircons with a peak at c. $1650 \mathrm{Ma}$. However, there is a second distinct Mesoproterozoic peak at $c .1360 \mathrm{Ma}$ in the northern area and a significantly reduced abundance of Mesoproterozoic zircon ages in the central area.
As expected, the detrital rutile ages peak just below 1000 Ma for all three samples, reflecting rutile formation or complete U-Pb system resetting of older rutile grains during medium- to high-grade metamorphic stages of the Grenville orogeny. Titanite shows Grenvillean ages for all three samples. In the sample from the southern interior magmatic belt all titanite ages are $c .1000 \mathrm{Ma}$ old, corresponding to the rutile age distribution, whereas a more complex age pattern, with Palaeo- and Mesoproterozoic titanites, is seen in the samples from the central and northern areas. This indicates that many more titanite grains from the latter areas survived the Grenvillean metamorphism than (1) rutile from the same areas and, (2) titanite and rutile from the southern interior magmatic belt. The occurrence of pre-Grenvillean titanite and absence of pre-Grenvillean rutile in the central and northern areas could be due to the difference in the U-Pb isotopic system closure temperatures of the two minerals; rutile has a lower closure temperature at $c .400-500^{\circ} \mathrm{C}$ than titanite with a closure temperature at $c .500-700^{\circ} \mathrm{C}$. Hence the age pattern depends on the metamorphic grade to which minerals were exposed during the Grenville orogeny. The occurrence of titanite ages and lack of rutile ages indicate medium- to high-grade metamorphic conditions, probably upper amphibolite facies. During the Grenville orogeny, the metamorphic grade of the new crust was probably higher in the southern interior magmatic belt than in the central and northern areas. We suggest that the closure temperature of
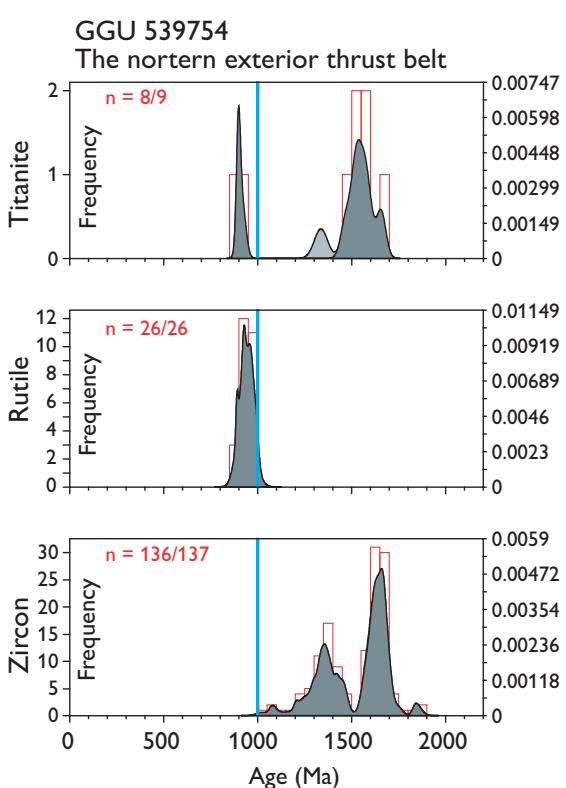
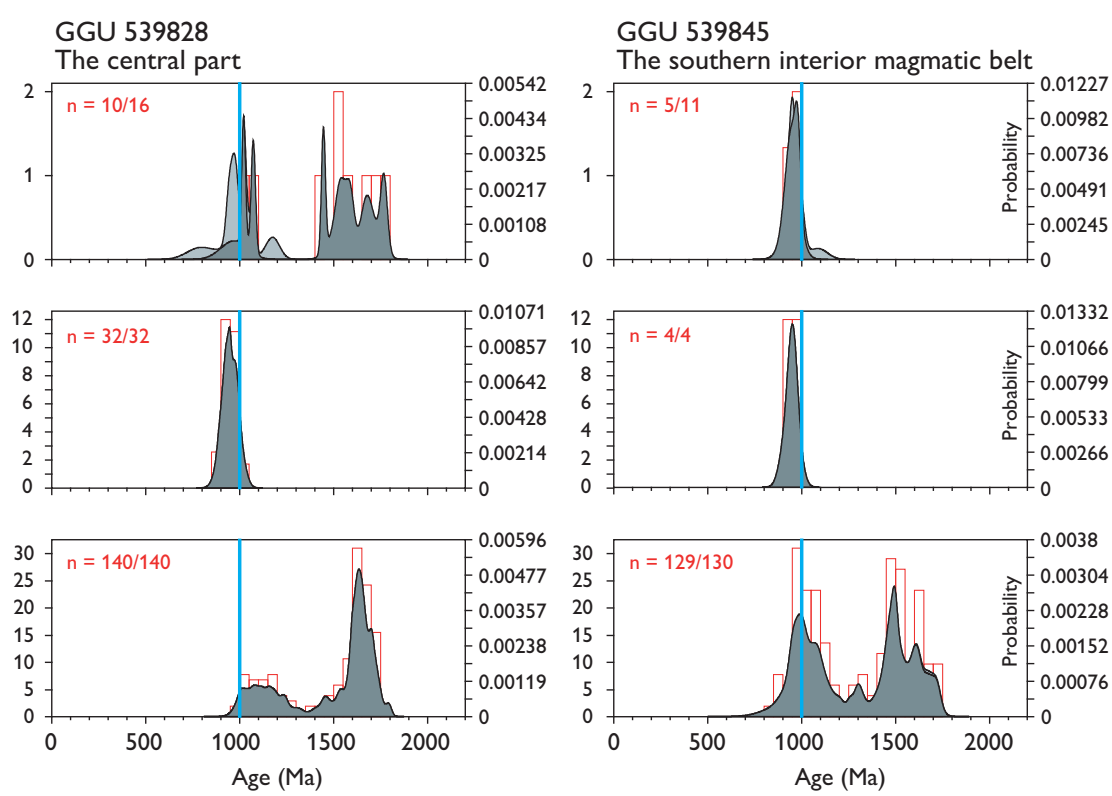

Fig. 2. Probability-density diagrams showing $\mathrm{U}-\mathrm{Pb}$ age distributions for three samples collected in Labrador. $\mathrm{n}=x / y$ (in red) denotes the total number of analysed zircon grains $(y)$ of which $x$ are 'concordant' (i.e. $<10 \%$ discordant from concordia). Light grey: ages that are $>10 \%$ discordant (relative to Wetherill concordia), dark grey: 'concordant' ages within $<10 \%$ discordance (i.e. $<10 \%$ ). Blue line at 1000 Ma: late stage of the Grenville orogeny. 
both Ti minerals was overstepped, resulting in isotopic age resetting of any pre-Grenvillean titanite and rutile grains and formation of new Grenvillean age titanite and rutile.

\section{Concluding remarks}

The wide range in the detrital zircon $\mathrm{U}-\mathrm{Pb}$ ages within the Grenvillean orogenic belt reflects formation age differences of the rocks that were brought into the orogenic process. Accordingly, for the best characterisation of the sediment source, it is not sufficient to know the age of the orogeny that affected the area; it is also nessesary to know the lateral distribution of the rock units in the area as well as the ages of the zircons (and other minerals) from these units. Moreover, different units contain different amounts of e.g. zircon. An efficient way to map the lateral age variation is to analyse detrital minerals collected from present-day drainage systems.

\section{References}

Fedo, C.M., Sircombe, K.N. \& Rainbird, R.H. 2003: Detrital zircon analysis of the sedimentary record. In: Hanchar, J.M. \& Hoskin, P.O. (eds): Zircon: experiments, isotopes and trace element investigations. Mineralogical Society of America, Reviews in Mineralogy 53, 277-303.

Force, E.R. 1980: The provenance of rutile. Journal of Sedimentary Petrology 50, 485-488.

Force, E.R. 1991: Geology of titanium-mineral deposits. Geological Society of America, Special Papers 259, 112 pp.

Frost, B.R., Chamberlain, K.R. \& Schumacher, J.C. 2001: Sphene (titanite): phase relations and role as a geochronometer. Chemical Geology 172, 131-148.

Krogh, T.E. \& Keppie, J.D. 1990: Age of detrital zircon and titanite in the Meguma Group, southern Nova Scotia, Canada: clues to the origin of the Meguma Terrane. Tectonophysics 177, 307-323.

McAteer, C.A., Daly, J.S., Flowerdew, M.J., Connelly, J.N., Housh, T.B. \& Whitehouse, M.J. 2010: Detrital zircon, detrital titanite and igneous clast $\mathrm{U}-\mathrm{Pb}$ geochronology and basement-cover relationships of the Colonsay Group, SW Scotland: Laurentian provenance and correlation with the Neoproterozoic Dalradian Supergroup. Precambrian Research 181, 21-42.
McAteer, C.A., Daly, J.S., Flowerdew, M.J., Whitehouse, M.J. \& Monaghan, N.M. 2014: Sedimentary provenance, age and possible correlation of the Iona Group, SW Scotland. Scottish Journal of Geology 50, 143-158.

Morton, A.C. \& Hallsworth, C.R. 1999: Processes controlling the composition of heavy mineral assemblages in sandstones. Sedimentary Geology 124, 3-29.

Muhling, J.R., Rasmussen, B. \& Fletcher, I.R. 2013: Dating deposition and low-grade metamorphism by in situ $\mathrm{U}-\mathrm{Pb}$ geochronology of titanite. Mineralogical Magazine 77, 1800 only.

Okay, N., Zack, T., Okay, A.I. \& Barth, M. 2011: Sinistral transport along the Trans-European Suture Zone: detrital zircon-rutile geochronology and sandstone petrography from the Carboniferous flysch of the Pontides. Geological Magazine 148, 380-403.

Paton, C., Woodhead, J.D., Hellstrom, J.C., Hergt, J.M., Greig, A. \& Maas, R. 2010: Improved laser ablation U-Pb zircon geochronology through robust downhole fractionation correction. Geochemistry, Geophysics, Geosystems 11, 1-36.

Paton, C., Hellstrom, J.C., Paul, B., Woodhead, J.D. \& Hergt, J.M. 2011: Iolite: Freeware for the visualisation and processing of mass spectrometric data. Journal of Analytical Atomic Spectrometry 26, 2508-2518.

Petrus, J.A. \& Kamber, B.S. 2012: VizualAge: a novel approach to laser ablation ICP-MS U-Pb Geochronology Data Reduction. Geostandards and Geoanalytical Research 36, 247-270.

Stacey, J.S. \& Kramers, J.D. 1975: Approximation of terrestrial lead isotope evolution by a two-stage model. Earth and Planetary Science Letters 26, 207-221.

Triebold, S., von Eynatten, H., Luvizotto, G.L. \& Zack, T. 2007: Deducing source rock lithology from detrital rutile geochemistry: an example from the Erzgebirge, Germany. Chemical Geology 244, 421-436.

Triebold, S., Luvizotto, G., Tolosana-Delgado, R., Zack, T. \& von Eynatten, H. 2011: Discrimination of $\mathrm{TiO}_{2}$ polymorphs in sedimentary and metamorphic rocks. Contributions to Mineralogy and Petrology 161, 581-596.

Zack, T., von Eynatten, H. \& Kronz, A. 2004: Rutile geochemistry and its potential use in quantitative provenance studies. Sedimentary Geology $171,37-58$.

Zack, T., Stockli, D.F., Luvizotto, G.L., Barth, M.G., Belousova, E., Wolfe, M.R. \& Hinton, R.W. 2011: In situ U-Pb rutile dating by LAICP-MS: ${ }^{208} \mathrm{~Pb}$ correction and prospects for geological applications. Contributions to Mineralogy and Petrology 162, 515-530.

Authors' adresses

T.B.T. \& C.K., Geological Survey of Denmark and Greenland, Øster Voldgade 10, DK-1350 Copenhagen K, Denmark. E-mail: tbt@geus.dk

A.M.H., Geological Survey of Newfoundland and Labrador, 50 Elizabeth Avenue, St. John's, NL, Canada. 